\title{
Comparison and Study on Ideological and Political Methods Home and Abroad
}

\begin{abstract}
With the development of society, the importance of ideological and political education has become increasingly obvious, and countries all over the world have paid much attention to ideological and political education, during which the methods of ideological and political education are of the same important role. Therefore, the key factor of improving practical effect of ideological and political education is to choose correct and proper educational methods since appropriate methods are the important conditions to realize educational goals, which can ensure the educational effect effectively. In this paper, several common educational methods are adopted as the basis to compare the representative methods of ideological and political education home and abroad. By comparing and studying the differences of Chinese-Western ideological and political educational methods, we can have a deep understanding of overseas ideological and political educational methods so as to promote the development and perfection of ideological and political educational methods in our country, which can provide new ideas for the innovation of ideological and political education with constant improvement and innovation.
\end{abstract}

Wei Fang

Jiangxi University of Technology times. promoted.
Keywords-ideology and politics; Chinese and overseas education; methods; comparison

\section{INTRODUCTION}

In today's world, the process of globalization has been accelerated with constantly larger range, which makes people's mind and values change greatly. In the new age, workers of ideological and political education have to recognize the condition with constant creation of methods so as to better implement ideological and political education as the environment, objects and contents are all changing greatly. Almost all countries in the world have paid increasingly more attention to ideological and political education with constant innovation and study on the ideological and political educational methods because the role of methods is huge, which can not only influence the transmission of educational information, but also affects the educational effect. Thus, both the selection and employment of methods are of great importance, which requires us to constantly develop and innovate the ideological and political educational methods advent the change of

By studying the overseas ideological and political educational methods through comparison with Chinese methods, method system of ideological and political education in China can be perfected, which can provide new ideas for the innovation of ideological and political educational methods as well as improve the practical effect. Thus, the innovation of ideological and political educational methods in China can be constantly

\section{METHODS OF IDEOLOGICAL AND POLITICAL EDUCATION AS WELL AS THEIR ROLES}

The methods of ideological and political education refer to a series of educational methods adopted by educators as well as educatees during the education practice to improve educational effect. Ideological and political educational methods during the education practice are very indispensable since the educational task or educational goals can't achieved without correct or proper educational methods. Besides, correct ideological and political educational methods should be suitable for the fundamental purpose and task of ideological and political education as well as the ideological fact of educatees. During the practice of ideological and political education practice, the methods are the most essential parts in the whole education.

The ideological and political educational methods are beneficial to the transmission of education information; and in turn, transmission of education 
information needs diversified channels and methods by taking vivid and active entertainment as carriers together with common theoretical guidance. Both the educational quality and the educational effect are directly related to the educational methods that educators adopt. Therefore, methods of ideological and political education play an important role in the transmission of ideological and political education information. Ideological and political educational methods are important guarantees for the accomplishment of educational tasks and educational goals as well as indispensable methods and skills for ideological and political education.

\section{ChINESE METHOdS OF IDEOLOGICAL AND POLITICAL EDUCATION}

\section{A. Theoretical educational method as well as its}

\section{characteristic}

Chinese theoretical education is based on Lenin's indoctrination theory as well as the basic theory of Marxism, including education of Marxist views on world, life and values as well as basic routes, guidelines and policies of CCP, and democratic and legal education and moral education. Mainly the lecture method is adopted by educators to give direct knowledge indoctrination to educatees.

\section{B. Educational method of social practice as well as its}

\section{characteristic}

In China, both theoretical education and practice education are important for ideological and political education, and practice education can be regarded as invisible course, which is implemented silently in education practice with importance to infiltration method, and it will have a long-term and potential influence on educatees. The method of practice education in China usually has strong nature of theoretical application as well as positive indoctrination in the whole practice with thoughtful planning, organization and arrangement. Thus it is well organized and planned with careful inspection and assessment.

\section{The method of invisible edification as well as its characteristic}

Application of invisible edification method in Chinese ideological and political education mainly manifests in the employment and reform of educational environment. By beautifying the social material and spiritual environment, educators make the educatees in a sound social circumstance. With the confinement of environment, educatees can have gradual perfection of themselves with improvement of moral literacy. This educational method integrates the contents of ideological and political education into rich, colorful, vivid and easy activities so that educatees can receive education information unconsciously, which can improve the efficiency of information reception with common emotional feelings and deep influence.

\section{OVERSEAS METHODS OF IDEOLOGICAL AND POLITICAL EDUCATION}

\section{A. American theoretical educational method}

Although there is no term of ideological and political education in America, their implementation of education is very clear since government has made clear requirements on the contents and goals of ideological and political education with many compulsory provisions on the curriculum settings in political subjects. American theoretical education pays much attention to the infiltration of ideological and political education in professional courses. In class, the invisible or comprehensive ways are more likely to be adopted by educators to conduct teaching.

\section{B. British theoretical educational method}

C. Britain is a country with a tradition of Christian religion, so religious education plays an important role in the ideological and political education in Britain as well as one characteristic part. Britain has always attached great importance to the convey of religious ideas, but they don't advocate obvious and indoctrinated ideas with standard answers; instead, they prefer to guide students to have self inspection and encourage them to explore knowledge by themselves. Ideological and political education outside British schools mainly rely on mass communication.

\section{Theoretical educational method in Singapore}

By infiltrating the government values to educatees with ideological and political eductaion, educatees can become good persons who can make contributions to 
national development. Singapore is a migrant country who has complicated population and diversified culture, which determines the role of patriotism in the its ideological and political education with great importance to national awareness as well as national belongings and recognition. Eastern values represented by Confucianism is vigorously advocated by Singapore government, in which Confucius values and concepts suitable for national development are imbued with young people to make them become ideal and moral people. They value theoretical education as well as the efficiency and practicability of education in order to avoid inefficient education.

\section{CONCLUSION}

With the development of science and technology, both the environment and objects of ideological and political education have been changed. Nowadays, ideological and political education must lead people to face modernization, the world and the future with establishment of open, updated and developmental knowledge views. In this paper, implementation methods of ideological and political education in different countries have been compared to master its operational rule; besides, by mutual references and integration, the development of ideological and political education can be further promoted. It is a major means to develop ideological and political education by learning experience from other countries. Some other countries have established a set of complete methods for the implementation of ideological and political education by their social development, within which the psychological consultation method and incentive method and so on are really effective, which are worthy to be referred.

\section{REFERENCES}

[1] Wang J, Xu C. Model Demonstration in College Ideological and Political Education:Exploration and Innovation[J]. Journal of College Advisor, 2012.

[2] Li, Yanchun, and W. Guo Cao. "Application of SPSS in the ideological and political education." Artificial Intelligence and Education (ICAIE), 2010 International Conference on IEEE, 2010:187-190.

[3] Li Y, Guo Cao W. Application of SPSS in the ideological and political education[C]// Artificial Intelligence and Education (ICAIE), 2010 International Conference on. IEEE, 2010:187-190.

[4] Yan F, Zhang C Y. Explorations on Micro-blog and Ideological and Political Education on College Students[J]. Journal of Shanxi College for Youth Administrators, 2012.

[5] Yu-Boa H U, Xingb X U, Zhao Y. New mode for blog-based ideological and political education on undergraduates[J]. Journal of Zhejiang University of Science \& Technology, 2008.

[6] Huang Y J. Ideological and Political Education: the Soul of Quality Education[J]. Journal of Lianyungang Technical College, 2002.

[7] SHEN Zhuang hai. On Theoretical Framework for Validation of Ideological and Political Education[J]. Teaching \& Research, 2001.

[8] Yang S. Challenges and Counter-measures in Ideological and Political Education Raised by E-governments[J]. Journal of Harbin Teachers College, 2003.

[9] Chen F. Study on Ideological and Political Education[C]// International Conference on Education, Management and Information Technology. Atlantis Press, 2015.

[10] Wang R. Comparative Study on Chinese and Germany University Ideological and Political Education Methods and the Enlightenment[J]. Science Education Article Collects, 2014.

[11] Lin L U. Ideological and Political Education for College Students daily[J]. Beijing Youth Research, 2014.

[12] Wang. Study of Ideological and Political Education of Chinese College Students Based on the Humanistic Care[J]. Review of Global Academics, 2014:301-303. 